\title{
Islamic Hire Purchase Law is Getting Special Attention in Malaysia: A Socio-Legal Analysis
}

\author{
Dr. Md. Abdul Jalil \\ Associate Professor of Business Law \\ Department of Business Administration \\ International Islamic University Malaysia (IIUM) \\ E-mail: abduljalil@iium.edu.my, abd_jalil2@yahoo.com,
}

Accepted: May 03, 2013 Published: June 01, 2013

Doi:10.5296/jsr.v4i2.3796 URL: http://dx.doi.org/10.5296/jsr.v4i2.3796

\begin{abstract}
The Muamalah Hire Purchase Bill (MHPB) was initially prepared by a group of members of the shariah supervisory council of Bank Islam Malaysia Berhad (BIMB) in 1991 and it was later submitted to the Ministry of Domestic Trade and Consumer Affairs in Malaysia and the Central Bank of Malaysia for review. Finally in the year 2000, it was referred to the Attorney General's Chamber for further examination whether it met the shariah rules and how it could be implemented in Malaysia. However, the Bill could still not be submitted to the Parliament until today for consideration and approval due to certain reasons. The objective of this paper is to discuss the nature of the Islamic hire purchase contract (IHPC) and to compare it with the traditional hire purchase contract (THPC) for purposes to find the difference between the two systems of law. Descriptive and analytical research methodology had been applied in this research paper to analyze the collected data.
\end{abstract}

Keywords: Traditional hire purchase contract (THPC), Hire Purchase Act (HPA), Muamalah Hire Purchase Bill (MHPB), Al-ijarah thumma al-bai (AITAB), Islamic hire purchase law (IHPL) etc.

\section{INTRODUCTION}

There is the Hire Purchase Act 1967 (Malaysia) (herein after referred to as HPA 1967) which deals with the hire purchase agreement in Malaysia. The Act is made based on the English higher purchase law. The provisions of the Act are fair to the hirer. It provides a fair treatment to the hirer of goods under a hire purchase agreement (Abdullah \& Razali, 2008). However, there are some provisions in the HPA that are not in conformity with the shariah (Islamic law) principles. Abdullah (2009) has argued that the HPA 1967 is not fully suitable for the Muslims in Malaysia and accordingly, therefore, she proposes for a separate Islamic 
hire purchase law which can be named as Muamalah Hire Purchase Bill (herein after referred to as MHPB). As mentioned in the abstract, such a Bill has in fact been prepared by some Muslim scholars in Malaysia. Nevertheless, some Islamic scholars find that although this Bill provides many provisions which are in line with the shariah principles but still it has some legal shortfalls. ${ }^{1}$

The Hire Purchase Act 1967 Malaysia (HPA 1967) has some provisions which are contrary to the Islamic contract law principles, for example, the HPA 1967 has a provision to take interest in a hire purchase contract made under the Act. ${ }^{2}$ Taking interest is strictly prohibited in the Islamic law. ${ }^{3}$ As Malaysia being a Muslim majority country, thus, the Muslims think that the existing HPA 1967 can only be used by the non-Muslims in conducting any hire purchase contract. However, the act is not applicable by the Muslims as it does not fully conform to the Islamic law principle as mentioned above, as a result of which the Malaysian Muslims decide that it is now the appropriate time that an Islamic Hire Purchase Act should be enacted for the Muslims in Malaysia. Some Muslim scholars in Malaysia say the proposed Act can be named as the Islamic Hire Purchase Act (IHPA) or the Muamalah Hire Purchase Act (MHPA). Muamalah is an Arabic term which means 'a transaction made based on the Islamic law principles'.

It is to be noted that the HPA 1967 (Malaysia) is not fully contradictory with the Islamic law principles as only certain sections are in contradiction with the Islamic contract law principles. Hence, some people may argue that as the HPA 1967 is 90 percent in line with the shariah (Islamic law) principles, the rest can be amended to fully conform to the shariah principles. However, this issue is compounded by the fact that Malaysia being a multi-national and multi-religious country, the existing HPA 1967 is only suitable for the non-Muslims, in which case the amendment proposal to the act is not carried out, as the best solution would be to enact a separate Islamic higher purchase law for the Muslims in Malaysia.

In this paper, we have discussed the basic features of the traditional hire purchase law and the Islamic hire purchase law. The paper presents some arguments from some Muslim scholars who prefer the enactment of the Islamic hire purchase law in Malaysia. As stated earlier, a descriptive and analytical research methodology has been applied in this paper to present the secondary information collected.

\section{DEFINITION AND CONCEPT OF HIRE PURCHASE AGREEMENT}

The Hire Purchase Act 1967 (Malaysia) (HPA 1967) has given a definition of the hire

\footnotetext{
1 Abdullah, N. Irwani. (2009) Implementation of Muamalah Hire Purchase Bill in Malaysia: Chasing a Mirage? IIUM Law Journal, 17: 118-120.

2 See, section 34(c) of Hire Purchase Act 1967 (Malaysia).

${ }^{3}$ The Quran, Surah Baqarah, (2):275.
} 
purchase agreement which is based on the English hire purchase law. Section 2(1) of the Act provides a definition of the hire purchase agreement which consists of two parts. The first part of the definition states, "Hire purchase agreement is a letting of goods with an option to purchase" and the second part states, "Hire purchase is an agreement for the purchase of goods by installments (the installments can be in the form as rent or hire or otherwise)."

So, the first definition of hire purchase says that an owner of goods can let his goods to the hirer for a periodical payment known as rent and can give an option to the hirer to buy the goods. The option can be exercised at the end of the rental period or within the rental period. In this case, the hirer has to pay a purchase price and the purchase price would be determined based on the provisions in the hire purchase agreement. Even it can be given free or for a nominal price let's say RM100 only. The second definition provides that a hirer can purchase the hired goods by paying installments and this installment can be termed as rental for the goods hired. The hirer can only get possession of the hired goods and can use it for the purpose for which it is hired but does not get ownership on the goods until he pays the last installment and all other dues (if any) are paid. If all the installments have been fully settled together with other charges (if any), the owner of the goods would pass the title on the goods to the hirer by transferring the goods in the name of the hirer through a registered deed.

Section 2(1) of HPA 1967 excludes the following two types of agreement from the ambit of hire purchase agreement. They are:

i. an agreement whereby the property in the goods comprised therein passes at the time of the agreement or upon or at any time before the delivery of the goods;

ii. an agreement under which the person by whom the goods are being hired or purchased is a person who is engaged in the trade or business of selling goods of the same nature or description as the goods comprised in the agreement.

Another important factor in the hire purchase agreement is that the goods hired should be 'consumer goods' and 'motor vehicles'. Section 2(1) of the HPA 1967 provides the definition of 'consumer goods' saying "consumer goods are goods that are purchased for personal, family or household purposes". Hence, if any goods are transacted on a hire purchase agreement for business purpose, they would not be considered as consumer goods and the hire purchase agreement would be null and void.

In Low Ping Ming v. MBF Finance Bhd, ${ }^{4}$ Steve Shim J described the nature of the hire purchase agreement in English common law. He stated, "A hire purchase agreement, at common law, is regarded as a form of contract whereby the owner lets goods out on hire and agrees that the hirer may either return the goods and terminate the contract or elect to buy the goods on the completion of the required periodic payments. A common characteristic or feature of such an agreement is that the hirer has the option of purchasing the goods. And throughout the period of the hire purchase agreement, title to the goods remains with the owner. Therefore, unlike a sale of goods contract, no title to the goods passes from the owner to the hirer during the period of hire."

${ }^{4}[2000] 2$ CLJ 307. 
In a hire purchase agreement, the hirer does not become the owner of the goods hired until he has paid all the installments under the agreement, and in such a case, he is not allowed under law to sell the goods or to give it to another person under a hire purchase agreement. This was decided by the court in the Credit Corporation (Malaysia) Bhd v. Malaysian Industrial Finance Corporation \& Anor. ${ }^{5}$ In this case, the plaintiff had entered into a hire purchase agreement with one Soo Peng Kum (the hirer) on March 31, 1971, in respect of a new Toyota Corolla car, bearing registration number JJ 1807. The vehicle was registered in the name of the hirer, with the plaintiff's claim of ownership endorsed on the Register and the registration card (the log book). When the hirer defaulted in his installment payments, the plaintiff repossessed the vehicle on June 18, 1973. At that point in time, the vehicle was in the possession of the second defendant. The car had the same chassis number but the registration number was changed to JJ 4733 instead of JJ 1807. The change of registration number was effected in December 1971.

The second defendant had purchased the car in February 1972 from a dealer in Batu Pahat and for this purpose a hire purchase agreement was entered into by him with the first defendant. The issue before the court was whether the second hire purchase agreement created any rights when the first hire purchase agreement was not complete and it was still continuing in force. The court held that until the hirer (first defendant) had exercised his option to purchase the car after paying all the installments, no property in the car had passed to him. Hence, the hirer could not pass any title to the second defendant.

In a hire purchase agreement, the owner of the goods has the right to take repossession of the goods from the hirer if he fails to pay two successive installments or the last installment under the agreement. In Tractors Malaysia Berhad v. Kumpulan Perminaan Malayisia Sdn Bhd. ${ }^{6}$, the appellant (as owner) had entered into a hire purchase agreement with the respondent (as hirer) in respect of a Caterpillar tractor. The hirer defaulted in repayment of installments and the tractor was repossessed, but upon settlement of the overdue installments the tractor was returned and the hire purchase agreement was revived. The hirer subsequently paid all the installments under the agreement and the owner of the tractor transferred it to the hirer's name.

Later the respondent (hirer) brought an action for damages against the appellant on the ground that the earlier act of repossession by the appellant (owner) was wrongful. The respondent alleged in his plaint that the transaction between the parties was an outright purchase and not a hire purchase agreement.

In the Federal Court of Malaysia, Chang Min Tat FJ held that on a proper construction of the agreement, it was beyond a doubt that the intention of the parties was that the property in the vehicle was not to pass to the respondent until full payment had been made and, hence,

\footnotetext{
${ }^{5}$ [1976] 1 MLJ 83.

${ }^{6}[1979] 1$ MLJ 129.
} 
the appellant being the owner of the tractor had the right to repossess the vehicle when the respondent failed to pay the installments under the agreement. Therefore, the repossession of the Caterpillar tractor performed by the appellant (the owner) was not wrongful.

Under the English common law there is a form of hire purchase agreement. The form has some sort of a similarity with the HPA 1967 (Malaysia) but not typically the same as provided in section 2(1) of the Malaysian Act. According to Buang, "Under common law, a hire purchase transaction is a contract whereby one party called 'the owner' lets goods on 'hire' to another party and agrees that the 'hirer' may either return the goods when he no longer needs them and terminate the hire purchase agreement, or elect to purchase the goods on completion of the necessary payments agreed in the contract. ${ }^{7}$ In such a case, under the English common law, the hirer is given an option either to purchase the goods at the end of the hiring period or within the hiring period after paying the necessary payment as agreed between the parties. If the hirer thinks that he does not need the goods he may elect not to purchase the goods and can return the goods. ${ }^{8}$

The English law provides that a hirer can only purchase the hired goods if he has fulfilled all the conditions agreed with the owner of the goods until the end of the hiring agreement. During the subsistence of the hiring contract, the owner of the goods remains as owner by virtue of the fact that the ownership does not pass to the hirer as has been stated earlier in this sub-heading. The hirer can only enjoy the possession of the goods by paying the periodical installment payments, thus, the hirer is not allowed to have a conversion of the goods. ${ }^{9}$ If he is liable for conversion, he will be punished according to the criminal law.

Hire purchase is actually a written agreement to letting goods with an option to buy after fulfilling all the conditions under the written agreement. Section 4A and 4B of the HPA 1967 (Malaysia) requires that all hire purchase transactions must be in writing and signed by the parties. Under the written agreement, goods are let on hire and the hirer has an option to purchase the goods in accordance with the terms of the agreement. The hire purchase agreement requires the owner to deliver possession of the goods to the hirer and the right to use the goods for his (hirer's) purpose. The hirer is required to pay the agreed amount as rent for the use of the goods in periodical installments. The agreement also provides that on the payment of the last installment, the property in the goods is to pass to the hirer who has entered into the hire purchase agreement on such terms. ${ }^{10}$

There is a difference between the sale of goods contract and the hire purchase contract. In a sale of goods contract, the possession and ownership are transferred to the buyer as soon as the contract is completed although the full payment is not made yet. In the sale of goods

\footnotetext{
${ }^{7}$ See, Buang, 2001, at 4; Coulson, 1984, at 10.

${ }^{8}$ See, Diamond, 1971, at 20.

${ }^{9}$ Buang, 2001, at 5.

${ }^{10}$ See, Hamid, 2008.
} 
contract, the ownership in the goods passes to the buyer when the contract is concluded and usually it is not a requirement that the property in the goods should pass when full payment will be made. ${ }^{11}$ However, if it is stipulated in the sale of goods contract that the title in the goods will not pass to the buyer until full payment is made, then the ownership in the goods will not pass to the buyer until a full payment is paid. ${ }^{12}$

On the other hand, as has been said earlier, in a hire purchase transaction, the ownership in the goods will not pass to the hirer on the execution of the hire purchase contract (Helby $v$ Mathews, 1895). The property in the goods will only pass to the hirer only when he has paid his final installment and other required payments and has decided to exercise his option to purchase the goods. ${ }^{13}$

\section{THE CONCEPT AND NATURE OF AL-IJARAH THUMMA AL-BAI (AITAB) TRANSACTION}

Al-ijarah thumma al-bai is known as AITAB transaction which is a shariah approved hire purchase contract. AITAB means 'hire goods and then purchase'. It has similar meaning with the Arabic terms ijarah muntahia bittamleek (IMB) which is practiced by the Muslims in the Middle East countries. ${ }^{14}$ Under the AITAB the owner of the goods lets it to the hirer for periodical installments (for instance, monthly rental) and the hirer is given an option to purchase the asset at the end of the hire purchase contract. The AITAB basically includes two contracts, such as, a) ijarah (leasing contract); and b) al-bai (sale contract). ${ }^{15}$ It is to be noted that AITAB or IMB has a similar meaning with the nature and concept of the Islamic hire purchase law (IHPL).

A hire purchase is a type of financial transaction used by the Islamic banks in the name of al-ijarah thumma al-bai (AITAB). This is also known as an Islamic hire purchase agreement. According to Salim (2008), in this type of business transaction, the owner of the goods lets it to another person for a specific rental and for a specified period of time as mentioned above. Usually the hirer is required to pay a monthly rental which is pre-determined and at the end of the rental period the hirer can buy it. Usually the purchasing of goods is evidenced in a separate sale contract for a nominal or mutually determined price. If the owner wants, he can sell the goods in the name of the hirer as a hiba (gift) at the end of the hire purchase agreement without any price. ${ }^{16}$

Like a conventional hire purchase contract, in AITAB, the goods pass to the hirer but the ownership remains with the lessor. The ownership in the goods only passes to the lessee/hirer only when he has paid all the installments of money agreed upon and fulfilled all

\footnotetext{
${ }^{11}$ See, section 4 of Sale of Goods Act 1957 (Malaysia).

${ }^{12}$ See, Sathiaseelan, 2008, at 21.

${ }^{13} \mathrm{Ibid}$.

${ }^{14}$ Ramli, 2007, at 21.

${ }^{15}$ Salim, 2008, at 30.

${ }^{16} \mathrm{Ibid}$, at 36.
} 
the other conditions, if any. The ownership in the goods is transferred by way of a new contract of sale of the goods in the name of the lessee/hirer. ${ }^{17}$ To be shariah compliance, an AITAB must conform to the basic requirements of the shariah, such as, (a) it must adhere to the essential elements of ijarah and bai contract and must meet the necessary conditions of each contract; and (b) avoid the relevant shariah prohibitions. ${ }^{18}$

The essential elements of the AITAB contract are as follows:

\section{The owner and hirer must:}

i. be of sound mind and not insane;

ii. have reached age of majority. Under the Age of Majority Act (Malaysia), the age of majority is 18 years. However, under shariah law the age of majority (bulug) is 15 years. It can be argued that 15 years age might be suitable for a marriage contract but to make a business contract, 18 years of age would be most suitable, because at this age, a person can understand better about the nature and obligation under the contract. ${ }^{19}$

iii. has not been forced or has not been under duress to enter into the hire purchase contract. They have entered into the contract based on a mutually free consent and full understanding of the nature and consequences of the contract.

iv. not a bankrupt and has not been restricted to do business;

v. not an extraordinarily extravagant person. In the Islamic law, an extravagant person is admonished. ${ }^{20}$

vi. be honest and muttaqin (fearful of Allah).

\section{Hire purchase asset}

Regarding the hire purchase asset, the following conditions should be fulfilled, such as, the asset:

i. must be in existence at the time of executing the contract. If the asset is not in existence at the time of hire purchase contract is made, such contract becomes invalid in shariah;

ii. can be delivered. The asset must be in a deliverable state to the hirer;

iii. must be halal (permitted) or pure otherwise the shariah (Islamic law) does not approve the hire purchase contract.

iv. be valuable and useful for the hirer's purpose. If the asset or goods to be delivered as ijarah (rent) is not in a workable condition, the hire purchase contract will be void.

v. be owned by the owner. The owner must have a legal title to the goods which he wants to deliver to the hirer under the hire purchase contract. If he is neither the owner nor he has any valid authorization to let the goods, he cannot execute a hire purchase contract with the hirer.

\footnotetext{
${ }^{17}$ Salim, 2008, at 36.

18 Ramli, 2007, at 2.

19 Jalil, 2010.

${ }^{20}$ Ramli, 2007, at 3.
} 
vi. be known and capable to be determined by the owner and hirer (substance not perishable). ${ }^{21}$

\section{Subject matter of hire purchase agreement}

According to Hasbullah (2005), the subject matter of sale (hired asset) must be something which satisfies the characteristics of a property (mal). The characteristics are:

i. It must have a value;

ii. It must be a thing which provides lawful benefits. In other words, the subject matter must be a lawful property in shariah. Hence, the sale of liquor or a casino building is prohibited by shariah; and

iii. It must be possessed by the owner and it must be a lawful property of the owner (seller).

The subject matter of hire purchase contract must have a valuable use as stated by Ramli above. It must be a useful asset. An asset that does not have any usufruct at all cannot be leased under the Islamic hire purchase contract. ${ }^{22}$

\section{Benefit or usage of the asset}

Regarding the benefit or usage of the asset, the following conditions must be fulfilled:

i. $\quad$ it can be valued with money.

ii. It has been known to the hirer and he has identified the asset.

iii. It should be used for the purposes that do not contradict the shariah principles.

iv. The hirer would be able to fully utilize the benefit of the asset.

v. Benefit to be derived from the asset for a specific period which should be determined for the hire purchase contract for the use of the asset.

vi. Benefit derived from the asset must not lead to the asset's destruction. ${ }^{23}$

\section{Rental of hire purchase asset}

Regarding rental of the hire purchase asset, the following conditions should be fulfilled:

i. The rental must be determined at the point where the hire purchase contract is concluded.

ii. The rental must be specific in terms of currency.

iii. The manner of rental to be paid. It is important to incorporate in the contract how the rental would be paid. Whether it would be paid on monthly installments or otherwise, should be clearly mentioned in the contract. ${ }^{24}$

\section{Validity of hire purchase contract}

To be a valid hire purchase contract, the contract must be prepared in a manner that is:

i. Definite, decisive and an absolute language.

21 Ibid.

${ }^{22}$ Usmani, 2002.

${ }^{23}$ Ramli, 2007, at 10.

${ }^{24}$ Ibid. 
ii. There should have a valid offer and an acceptance.

iii. The acceptance must be by free consent of the hirer and the owner.

iv. The interval between the offer and its acceptance must be within the customary practice.

v. Neither the offer nor the acceptance of the contract should be made conditional upon an event that is extraneous to the contract. ${ }^{25}$

\section{Validity of AITAb}

To be a valid AITAB, it must be free from any of the following factors:

i. Usury (riba);

ii. Gambling (maisir);

iii. Ambiguity and uncertainty (gharar);

iv. Haram (prohibited) and impure goods;

v. The goods are of no value and use.

\section{Transfer of ownership}

When the ownership of the goods rented is transferred to the hirer's name the following popular ways and conditions of transfer would be followed:

i. On nominal value, for example RM100.

ii. Last installment of rental has been paid and there are no more arrears or outstanding instalments.

iii. Full settlement of all installments and other dues in case of early settlement of payment and purchasing the goods.

iv. The goods can be transferred to the hirer's name by way of hiba (gift) without payment of any price as said above provided that the hirer has paid all the installments and dues.

There may exist a risk with the property rented under AITAB, for example, the asset is damaged by accident or destroyed by fire and so forth, thus, it is important to protect the asset by way of risk insurance coverage. The owner must ask the hirer to take the takaful (Islamic insurance) to cover the risk on the asset rented. The takaful should be taken either in the name of the owner or the hirer. The owner can ask the hirer to pay the insurance premium and it will be part of the monthly installments to be paid by the hirer.

\section{The Traditional Hire Purchase Contract (THPC) and Al-Ijarah Thumma Al-Bai (AITAB) Compared}

The conventional hire purchase law was made long before the AITAB concept originated. The conventional hire purchase contract has been practiced for the last two centuries in Europe and other countries. But the AITAB concept is of recent origin, just few decades ago. There is not much difference between the AITAB and the conventional hire purchase contract which is found in the Hire Purchase Act 1967 (Malaysia) (HPA 1967), as stated earlier. 
The HPA 1967 (Malaysia) is very developed and comprehensive and is adoptable in the present time as a fair and reasonable law protecting both the interest of the owner and the hirer in reasonable terms. The majority of the provisions provided in the HPA 1967 can be adopted into the Islamic hire purchase law (AITAB) as they are not contradictory with the shariah principles. Abdullah (2009) has also similarly viewed in her article that:

"The HPA provisions clearly spell out procedural rules and requirements which aim to make a hire-purchase transaction a success, and at the same time, to protect the hirer and guarantors by imposing certain duties onto the owner. These rules are clearly in line with the spirits of the shariah which promote justice and forbid oppression while engaging in commercial transactions. Therefore, the AITAB facility should not be prevented from adopting these rules and incorporating them in the agreement. Even in terms of management, it is permitted to refer to the conventional hire purchase and the prevailing practice (urf) at a particular place, as long as such practices are not against the shariah principle". 26

Hence, there are major similarities between the THPC and AITAB with only some small differences. Ramli has pointed out seven differences between the two types of hire purchase law. ${ }^{27}$ They are as follows:

i. AITAB contract is based on the shariah principles and it includes many provisions from the HPA 1967. Whereas, THPC is based on the Hire Purchase Act 1967.

ii. Under the AITAB, during the ijarah (lease) contract, the responsibility for bearing maintenance costs (for example repair costs) rests with the lessor, unless, the agreement provides otherwise. Whereas, in THPA the market practice states that the lessee is to bear the maintenance costs.

iii. The asset to be leased under the AITAB contract must be deemed halal under the shariah. It must not involve haram (prohibited) elements, such as gambling, alcoholic beverages, or swine. Whereas, in the THPC there is no such prohibition on the haram assets to be made the subject matter of the hire purchase contract.

iv. There are two contracts in the AITAB, and some Islamic scholars required them to be made separately. Those two contracts are: i. lease contract; ii. sale contract. According to some Muslim scholars, if the two contracts are combined together the hire purchase contract will be invalid. According to Zuhaily (2002), if the transaction comprised of two contracts at the same time on the same subject matter, like leasing contract and selling contract concurrently; it is not allowed by the shariah. ${ }^{28}$

The conventional hire purchase is a hiring of goods with an option to purchase at the end of the agreement period, hence, it includes two agreements in one contract. On the other hand, an AITAB involves two transactions undertaken in sequence; ijarah (leasing) in the first phase and bai (sale and purchase) in the second phase. In this case, there should be two

\footnotetext{
${ }^{26}$ Abdullah, 2009, at 118 .

${ }^{27}$ Ramli, 2007, at 7.

${ }^{28}$ Zuhaily, 2002.
} 
separate contracts in the AITAB. The principles of each transaction must be observed in its respective stage.

It is necessary to state at the out set that, there is no clear shariah prohibition in combining the two contracts in the AITAB transaction whereby combining the two contracts into one Islamic hire purchase contract. It does neither cause any harm to any parties in the hire purchase contract nor does it go against any shariah principles. Therefore, it might be argued that the minority opinion of the Muslim ulamas (scholars) who oppose the combination of the two contracts might be ignored. ${ }^{29}$ Besides, combining two contracts into one contract is feasible and better than making two separate contracts on the same subject matter of the hire purchase contract.

To compare with the THPC, it requires that the two contracts should be combined into one contract as has been provided in the Hire Purchase Act 1967 (Malaysia), section 2(1). Hence, the provision in the HPA 1967 can be adopted into the AITAB as no harm will be caused to the parties and there is no clear shariah prohibition in this regard.

v. According to the AITAB transaction, the transfer of ownership of the hire purchase asset should be performed and evidenced in a separate contract. This view is acceptable in the sense that the separate contract for transfer will act as a deed of transfer of the goods to the hirer and it will also work as an evidence of transfer of title. Whereas in the THPC, ownership in the hire purchase asset is transferred automatically upon settling the final rental installment and any other dues deemed payable and therefore, the making of a separate sale contract under the THPC is thus redundant and unnecessary. However, the THPC does not prohibit or discourage the making of a separate contract for the transfer of ownership in the hire purchase asset if the legal circumstantial situation demands its performance.

vi. According to the Bank Negara Malaysia (BNM) circular, the hirer must pay compensation charges of $1 \%$ per annum to the owner. However, the AITAB prohibits taking interest (riba) on the hire purchase transaction. Even if the hirer is late to pay installments, the owner cannot claim interest on late payment but probably the AITAB may allow imposing penalty in terms of fine for late payment of installments. Whereas, in the THPC, the hirer has to pay $8.5 \%$ interest per annum for late payment of installments. This has been provided in section 34 of the HPA 1967. Section 34(C) of the HPA 1967 provides on this regard, "the hirer is required to pay interest on any overdue installments at a rate not exceeding eight per centum per annum simple interest calculated on a daily basis or such other rate of interest as may be prescribed." This provision of the HPA is not permitted in the AITAB. It is directly contradictory to the shariah principle.

vii. In the AITAB contract, the owner can only buy the asset to be given as a lease by taking money from the Islamic pool of funds. Whereas, in the THPC, the owner can take fund from the conventional pool of funds. In this regard Abdullah (2005), states in her Ph.D. thesis that AITAB follows the shariah principles as well as the spirit of

${ }^{29}$ Jalil, 2010. 
the Hire Purchase Act 1967, while the conventional hire purchase follows only the HPA. The source of funds in the AITAB facility is derived from permissible (halal) funds only. It means that the fund should not come from the shariah prohibited activities, such as, gambling, prostitution, bar or club which sells liquor, etc. This requirement has been observed by all the financial institutions and monitored by the Central Bank. In contrast, there is no limitation of its sources of funds in the conventional hire purchase facility.

There are additional differences between the THPC and the AITAB transactions and they are as follows:

viii. There is a difference between the THPC and the Islamic Hire Purchase Law (IHPL) on thetransfer of ownership in the hire purchase asset. It is to be noted that the IHPL and the AITAB have similar meaning and implications on the hire purchase law in shariah. Some Muslim scholars raise the issue on how transfer of the ijarah property should be completed. Whether the transfer would be automatic under the hire purchase contract or a separate sale contract should be prepared and signed by the parties. In this regard, some Muslim scholars mention that the transfer of ownership in the ijarah goods (by way of sale) must be evidenced in a separate contract as has been mentioned earlier. ${ }^{30}$

ix. The scope of goods under the AITAB is of wider range of goods as compared to the THPC. Under the HPA 1967, only consumer goods and motor vehicles are covered (Section 2(1) of HPA 1967). It does not cover industrial equipments and heavy machineries. Thus, there are many types of goods that cannot be contracted under the THPC. However, they are covered under the AITAB. In the MBF Finance Bhd. V. Ting Kah Kuong \& Anor, ${ }^{31}$ the facts of this case have been mentioned earlier where the court considered the definition of motor vehicles under section 2(1) of the HPA to determine whether a particular heavy lifting machine, for instance, a crane or forklift, can be regarded as motor vehicle, and thus subject to the Hire Purchase Act 1967. The court in Malaysia held that a forklift was not a motor vehicle and therefore the agreement was not subject to the Hire Purchase Act 1967.

Under the AITAB, a wide range of goods are included other than the goods included in the HPA 1967. It includes houses, industrial equipments, machineries, real property etc. The inclusion of a wide range of goods in the Muamalah Hire Purchase Bill (MHPB) in Malaysia has indeed enhanced the efficacy of the of the Bill and has made it more acceptable to the people in Malaysia, because it was desired by the people that the range of goods should be increased in the HPA 1967 including industrial equipments and non-goods, for example, real property, such as, house, apartment, land etc. The Islamic Hire Purchase Law (IHPL) accepts this extension of goods and non-goods items in the hire purchase agreements.

$x$. Another difference between the two concepts is that in the AITAB contract, the relation between the hirer and the bank is like that of a buyer and a seller but in the THPC, the relation is like that of a debtor and a creditor.

\footnotetext{
${ }^{30}$ Zuhaily, 2002.

${ }^{31}$ [1993] 3 MLJ 73.
} 


\section{IMPORTANT FEATURES OF HIRE PURCHASE ACT 1967}

The Hire Purchase Act (1967) (Malaysia) came into effect on 11 April 1968. This Act provides detailed and comprehensive provision governing the hire purchase agreement in Malaysia. The Act is up to date and provides all the necessary provisions for the formation of the hire purchase agreement. It also specifically states the duties and responsibilities of the hirer, the owner and the dealer of the goods.

In this Act, a 'dealer' has a special meaning. He is not an owner of the goods. His function is basically to negotiate between the hirer and the owner of the goods leading to the formation of a hire purchase agreement. Section 2(1) of the Hire Purchase Act 1967 (Malaysia) provides a definition of the word 'dealer'. The section states that: 'A dealer means a person, not being the hirer or the owner or a servant of the owner, by whom or on whose behalf negotiations leading to the execution of a hire purchase agreement with the owner were carried out or by whom or on whose behalf the transaction leading to a hire purchase agreement with the owner was arranged.'

In this case, the function of a dealer under the act is like a negotiator or an agent on behalf of the owner of the goods to let the goods on hire purchase agreement. Sections, 8, 36, 36C, 36D, 47 etc. of the Hire Purchase Act 1967 (Malaysia) (the HPA 1967) provides detailed provisions stipulating the duties, functions and responsibilities of a dealer.

The dealer has a civil liability under section 8(1) of the HPA 1967 for giving misrepresentation to the hirer. Section 8 of the HPA 1967 provides that a representation, warranty or statement made by a dealer or his agent is deemed as if it was made by an agent of the owner. Section 8(1) of the HPA 1967 confers the following rights to the hirer against the dealer for making a representation. Those rights are:

i. As against the owner, the right to rescind the agreement even if the fraudulent representation, warranty or statement was made by an agent of the owner; and

ii. As against the person or agent who made the representation, warranty or statement, the hirer has the right to take action for damages, as if the hirer had purchased the goods from that person.

Hence, section 8(1) of HPA provides the right to the hirer to rescind the contract against the owner and can claim damages from the dealer as an agent of the owner for making fraudulent representation, warranty or statement.

Section 36 of the HPA provides a penalty against the dealer if he makes false statements etc. to the hirer of goods. According to this section, making a false statement or a representation in an agreement or an offer in writing, by a dealer, an agent or a person acting on behalf of the owner, will be tantamount to a serious offence. If convicted, the dealer shall be liable to a fine not exceeding RM3,000 32 or to imprisonment for a term not exceeding six

\footnotetext{
${ }^{32}$ RM means Malaysian Ringgit.
} 
months or to both.

The HPA authorizes a dealer to collect payment from the hirer (Section 36B of HPA1967). However, he is not allowed to collect payment other than those provided in the Second Schedule of the Act (Section 36A of HPA 1967). Section 36C of the HPA requires that when a dealer collects payment from the hirer he must issue a receipt in respect of the payment. If the dealer has ceased to be authorized to collect payment from the hirer, it is the duty of the owner to inform the hirer that the dealer has ceased his authority to collect payment (Section 36D of HPA 1967).

Part II of the HPA 1967 provides detailed provisions on the formation and contents of a hire purchase agreement in section 4 - 5. Section 4(1)(a) of the HPA requires the owner or his agent to provide the hirer with a written statement duly completed and signed by him. The written statement basically provides particulars of goods and the hirer's financial obligations, such as, cash price, deposit, freight charges, vehicle registration fee, insurance and term charges.

Section 4A of the HPA 1967 is very important as it provides that a hire purchase agreement must be in writing otherwise, it shall be void and not enforceable by law. Hence, an oral hire purchase agreement is not recognized and acceptable under the HPA 1967. Section $4 \mathrm{~B}$ of the HPA requires that the hire purchase agreement must be signed by the parties.

Section $4 \mathrm{C}$ of the HPA requires that the agreement must specify all important contents in it. The contents are:

i. $\quad$ Specify a date on which the hiring shall be deemed to have commenced;

ii. Specify the number of installments to be paid under the agreement by the hirer;

iii. Specify the amount of each of these installments and the person to whom and the place at which the payments of these installments are to be made;

iv. Specify the time for the payment of each of those installments;

v. Contain a sufficient description of the goods to identify them;

vi. Specify the address where the goods under the hire purchase agreement are.

Section 5 of the Act requires the owner of the goods to serve on the hirer and the guarantors a copy of the hire purchase agreement within fourteen days after it is made. If the owner fails to comply with this requirement it will render the hire purchase agreement unenforceable by the owner but the agreement will not be void.

Part III, IV and V of the HPA 1967 provides protection for the hirer and the guarantors under the hire purchase agreement. These provisions provide certain rights and obligations to both the hirer and the guarantors. Part 4 also provides duties and responsibilities of the owner while taking possession of the goods for default in payment of installments.

Section 7 of the HPA provides certain implied conditions and warranties for the 
protection of the hirer against unscrupulous owner of goods. These implied conditions and warranties are very crucial for the hirer as they provide some implied rights to him which he can claim automatically without expressly including in the hire purchase contract. Those implied conditions and warranties are:

i. Implied warranty as to a quiet possession;

ii. Implied condition as to title (ownership) of the goods;

iii. Implied warranty as to be free from charge or encumbrance;

iv. Implied condition as to hirer's purpose;

If an owner or dealer breaches any of the above implied condition, the hirer has the right to rescind the contract. ${ }^{33}$ However, if a warranty is breached, the hirer is not entitled to rescind the contract but he can claim damages from the owner of the goods. ${ }^{34}$

The owner must have a genuine title in the goods which he is letting under the hire purchase agreement. In the Public Finance Bhd v. Ehwan Bin Saring, 1996, the High Court of Malaysia held that the owner should have a good title in the goods when the hire purchase contract was made and not when the final payment was made. In this case the owner of the goods did not have a good title in the goods when the hire purchase contract was made. Therefore, the hirer was entitled to rescind the contract and could recover the amount of the money already paid.

The HPA 1967 provides provisions for the repossession of goods from the hirer. When goods are repossessed by the owner for failure of the hirer to pay two consecutive installments or the last installment, the hirer is given certain rights and the owner has to follow a proper procedure provided in the hire purchase Act 1967. If the owner does not follow the procedure provided in the Act, the repossession of the goods will be invalid and he will be liable for an offence. ${ }^{35}$

The HPA 1967 provides specific procedures for repossession of goods from the hirer. Section 16 to 20 of the Act provides procedures for repossession. As mentioned earlier, the Act is very fair on the hirer as it provides an ample opportunity to the hirer to avoid repossession and it also gives a reasonable opportunity to the hirer to recover the goods even after the repossession of the goods by the owner.

Section 16(1) of the Act provides that if the owner of the goods wishes to repossess the goods from the hirer for breach of the hire purchase agreement, a written notice of 21 days must be submitted to the hirer. The notice must be in the form set out in the Fourth schedule of the Act. A second notice must be sent to the hirer after 14 days of submission of the first notice under the Fourth schedule. The second notice will remind the hirer to act promptly to settle the installments due, otherwise the owner will take repossession of the goods after the expiry of 21 days of the first notice.

\footnotetext{
${ }^{33}$ Vohrah and Aun, 2010.

${ }^{34}$ Majid and Arjunan, 2007; Pheng \& Detta, 2010.

${ }^{35}$ Pheng \& Detta, 2010.
} 
The HPA provides some more duties of the owner of the goods after repossession, and it also provides procedures before and after the sale of repossessed goods (Section 16(3) and (4) of the HPA). On repossession of the goods the owner must deliver to the hirer personally a document acknowledging the receipt of the goods. If the hirer is not present at the time of repossession, such document of receipt must be sent to him immediately after the owner takes possession of the goods (Section 16(4) of the HPA). The owner has to set out in the acknowledgement of receipt document a short description of the goods repossessed, the date, time and place of repossession. ${ }^{36}$

Within 21 days after taking repossession of the goods, the owner has to serve on the hirer and every guarantor of the hirer a 21-day written notice in the form set out in the Fifth Schedule of the Act (Section 16(3) of the HPA). The intention of this notice is to give the last chance to the hirer to pay all the installments due and other charges and recover the goods from the owner. ${ }^{37}$

The owner must not sell or dispose of the goods after taking repossession without a written consent from the hirer until the expiry of 21 days after the service of the Fifth schedule notice (Section 17(1) of the HPA). If he contravenes this rule, he shall be guilty of an offence under the HPA.

After the expiry of 21 days of service of the Fifth Schedule of notice, the owner can sell the goods to anybody at the price mentioned in the Fifth schedule of notice without obtaining consent from the hirer. However, if the owner intends to sell the goods in a public auction, he must notify the hirer of such public auction at least 14 days before the auction date (Section 18(4)(a) of the HPA). If the sale is to be other than by public auction, the owner must give the hirer an option to purchase the goods at the price at which he intends to sell them if the price is less than the owner's estimate of the value of the goods as stated in the notice served under the Fifth Schedule of the Act (Section 18(4)(b) of the HPA). If the owner fails to serve the above mentioned requisite notice or an option to purchase the goods to the hirer, he will be liable for an offence under Section 18(4) of the HPA. ${ }^{38}$

The HPA offers the hirer certain rights after repossession of the goods. The hirer, after receiving the 21-day notice issued under the Fifth Schedule, is entitled to regain possession of the goods by fulfilling the following conditions:

i. He has to pay all the installments due and other charges, if any;

ii. He has to pay damages for breach of the hire purchase contract;

\footnotetext{
${ }^{36}$ Section 16(5) of the HPA 1967 (Malaysia).

${ }^{37}$ Vohrah \& Aun, 2010.

${ }^{38}$ Pheng \& Detta, 2010.
} 
iii. He has to pay to the owner the reasonable expenses incurred by him (the owner) in taking repossession of the goods and redelivering them to the hirer if a settlement has been reached. ${ }^{39}$

Under the English law, the Hire Purchase Act 1965 (UK), the hirer has the right to terminate the hire purchase agreement at any time by giving a notice to the owner, but he remains liable to pay all the installments which have fallen due before the termination (Diamond, 1971: 115). Section 27 of the UK Act states on this regard that: 'At any time before the final payment under a hire-purchase agreement falls due, the hirer shall be entitled to terminate the agreement by giving notice of termination in writing to any person entitled or authorized to receive the sums payable under the agreement.'

Under the New Zealand hire purchase law, the hirer will be liable for an offence if he cheats the owner of the goods by selling the goods or by removing the goods from where it is supposed to be kept under the agreement without the consent of the owner. Section 44 of the Hire Purchase Act 1971 (New Zealand) provides that every person who with intent to defraud the vendor parts with possession of or purports to sell or removes or attempts to remove or does not act in relation to the goods comprised in a hire purchase agreement commits an offence and is liable to imprisonment for a term not exceeding 3 months or to a fine not exceeding $\$ 500$ or to both. ${ }^{40}$ The New Zealand hire purchase law like the Malaysian law allows the owner of the goods under the hire purchase agreement to take repossession if the hirer fails to pay two successive installments or the last installment. While taking repossession, the hirer should not obstruct the process of execution of legitimate repossession by the owner or his agent otherwise than by law. Section 26(6) of the Hire Purchase Act 1971 (New Zealand) provides that it is an offence for any person to obstruct a vendor or his agent lawfully exercising a power of repossession. ${ }^{41}$

The guarantor under the hire purchase agreement is liable to pay the installments defaulted by the hirer as he has guaranteed for this purpose to the owner of the goods. ${ }^{42}$ Section 22 of the HPA limits the liability of the guarantor. It provides that, a guarantor shall not be bound:

i. to pay to the owner an aggregate sum which is larger than the balance originally payable under the agreement; or

ii. to perform an obligation in respect of the goods that are not included in the hire purchase agreement and in the HPA.

Section 24 provides certain rights to the guarantor against the hirer when a guarantor has paid the overdue installments on be half of the hirer. Those rights are:

\footnotetext{
${ }^{39}$ Abdullah \& Razali, 2008, at 118.

${ }^{40}$ Dugdale, 1978, at 72.

${ }^{41}$ Ibid.

${ }^{42}$ Vohrah \& Aun, 2010.
} 


\section{MInstitute Macrothink}

Journal of Sociological Research

ISSN 1948-5468

2013, Vol. 4, No.2

i. The guarantor is entitled to be indemnified by the hirer against any claim made by the owner on the guarantee;

ii. An expressed or implied right of indemnity in respect of the sums paid out in the discharge of his obligation as a guarantor;

iii. The guarantor may compel the hirer to pay the installments in respect of the hire purchase agreement as and when they fall due. He may apply to a Magistrate for an order to that effect; and

iv. The guarantor is entitled to a right of subrogation when he pays the owner. In this case, the owner must assign to the guarantor all his rights against the hirer, including any securities taken in respect of the hirer's obligation under the hire purchase agreement.

Part VI of the HPA talks about insurance requirements in section 26-29. Section 26 requires an owner to take out an insurance cover in the name of the hirer. In case of motor vehicles, the obligation is limited to the first year of the agreement. The hirer will have to renew the insurance for the subsequent years. For other goods, the owner is obliged to bear the insurance cost for the duration in which the goods remains under the hire purchase agreement and such cost can be included in the hire purchase price.

\section{IMPORTANT PROVISIONS IN MUAMALAH HIRE PURCHASE BILL (MHPB)}

We have stated earlier that a Muamalah (Islamic) Hire Purchase Bill (MHPB) was prepared in 1991 by some prominent Islamic scholars who were members of the shariah supervisory council of Bank Islam Malaysia Berhad (BIMB). The Bill was submitted to the Ministry of Domestic Trade and Consumer Affairs in 1991 and then to the Central Bank of Malaysia for review. The Bill was also submitted to the Attorney General's Chamber in 2000 and it was examined by the shariah experts in the Islamic Division of the Prime Minister's Department. The Malaysian government was in favour of the Bill but it could not be passed as a law for some reasons, for example, the government was not sure whether to come up with a separate and new Muamalah (Islamic) Hire Purchase Law or to incorporate Islamic hire purchase law principles into the existing Hire Purchase Act $1967 .{ }^{43}$

The contents of the MHPB have been provided in the Bill in detail and we are not reproducing them here. The important thing is that the contents of the MHPB are typical to the HPA 1967. The MHPB was mainly drafted by reference to the Hire Purchase Act 1967 and, therefore, it is not surprising that most of its provision are identical to the HPA.

The Bill is divided into 9 parts and it has six schedules. The good things in the Bill are that it abolishes the provision for interest (riba) in HPA 1967. The HPA 1967 provides provisions for the payment of interest (riba) in section 34(c), in the Sixth Schedule on the 'terms charges', section 2, under the 'Statutory rebate' etc. The Second Schedule of the MHPB provides that the Islamic hire purchase law will operate based on the interest free

${ }^{43}$ Abdullah, 2009, at 114. 
Islamic transaction of 'al-bai al-murabahah'. This provision is very important because Islam prohibits interest in any business or social transaction.

The First Schedule of the MHPB includes a wider range of goods than the goods provided in the HPA 1967. The MHPB includes house and industry equipments, such as, machinery as goods can be rented under the Islamic hire purchase law. Actually a house is not goods but it is included in the MHPB and this inclusion will be very beneficial for the people who want to own a house based on the Islamic hire purchase agreement. However, it is not clear whether the Bill includes lands. The Islamic hire purchase law allows "land" to be rented on a hire purchase agreement. The Bill clearly states the purpose, calculation, method and procedure of payment and other essentials relating to the monetary aspects. These cover the calculation of profit margin, penalty for late payment, pre-payment or deposit, fees and charges and rebate (ibra) payment.

As has been stated earlier, some Islamic scholars do not agree that the lease contract and sale contract should be combined into one hire purchase contract. In view of this anomaly, the MHPB clearly provides that the hire purchase agreement shall comprise two distinct contracts, namely: i) the leasing contract and, ii) the sale and purchase contract. AAOFII Shariah Rules also provides similar rules. With respect to the above matter, we bear different views from the Islamic scholars who oppose the combination of two contracts in one Islamic hire purchase contract. Our argument is that combining the hiring contract and the sale contract in one single contract is not clearly prohibited by the Quran or hadis (the sayings, deeds and tacit approvals of prophet Muhammad). Another point is the combination of the two contracts does not contradict any of the established Islamic law principles. It is, therefore, inherently relevant that the Islamic fiqh Academy Jeddah has allowed the combination of the ijarah (lease contract) and the sale contract if the subject matter is the same in both cases. ${ }^{44}$

\section{ARGUMENTS FOR A SEPARATE ISLAMIC HIRE PURCHASE ACT}

The majority of the Muslims in Malaysia prefer a separate Islamic Hire Purchase Act (IHPA) for the Muslims. If a separate Islamic hire purchase law is enacted, the Muslims in Malaysia will be happy as they want to observe the Islamic mode of transactions in all aspects including buying goods on a hire purchase contract. Many academic scholars prefer a separate hire purchase law in Malaysia for the Muslims, for example Abdullah (2009) prefers a separate Islamic hire purchase law (IHPL) instead of amending the existing HPA by incorporating in it the shariah principles, because the amendment to the HPA 1967 still would not meet all the shariah requirements. For example, if the Islamic hire purchase law is enacted, a separate shariah court with appellate jurisdiction and shariah enforcement authority etc. will be needed to hear disputes related to the Islamic hire purchase law. The judges, lawyers and the shariah enforcement authority must have adequate shariah knowledge on the Islamic hire purchase law, procedure etc. to implement the law properly.

${ }^{44}$ Abdullah and Razali, 2008, at 123. 
A separate Islamic Hire Purchase Act (IHPA) might be enacted based on the 'al-ijarah thumma al-bai' (AITAB) or 'al-bai bithaman ajil' (BBA) principles. These two types of Islamic transactions are interest free, thus, it will encourage the Muslim or the non-Muslim to buy goods based on the Islamic hire purchase law if the proposed law is enacted based on either of the above two Islamic financial principles which are interest free.

Several educated people with the Islamic knowledge do not support the implementation of the Muamalah Hire Purchase Bill (MHPB) because it has many deficiencies and drawbacks. It is also very much similar to the HPA 1967. As such, many references in procedure and documentation have to be referred to the HPA and the civil court may have jurisdiction to hear the MHPB cases as these related to the Islamic banking are heard by the High Court in Malaysia. The MHPB is silent on many important provisions related to the repossession of hire purchase goods, such as, the hirer's right during repossession as provided by the HPA 1967 regarding exemption from paying cost of repossession if the hirer returns the goods within the prescribed period, the right to require the owner to sell the goods to any person recommended by the hirer, the right of the hirer to regain possession of goods after paying all the dues within the prescribed time. This indicates a glaring inadequacy of the MHPB.

The Bill does not provide a proper legal structure to try disputes related to the hire purchase based on the shariah principles. Such legal structure comprises police, prosecution team and judiciary. The Bill does not provide anything about the need to have a shariah court to hear the decisions related to the Islamic hire purchase. To hear disputes which may arise from Muamalah hire purchase law, the shariah court should have a jurisdiction to hear the case and the shariah court should have an appellate jurisdiction to decide the case finally. At present the traditional contract law is used to decide the Islamic banking cases in the civil courts. In such an untenable judicial situation, there is a possibility that cases related to the Islamic hire purchase will also be heard in a High Court which will apply the civil law instead of the Islamic law as stated above. ${ }^{45}$

It is to be noted that the current status of the shariah courts in Malaysia can be judiciously considered to be far below the status of the civil courts in terms of its limited jurisdiction to hear and have a final decision in most cases. This is due to the predominance of the conventional law in Malaysia. Another drawback of the Muamalah Bill is that it does not state anything about the appointment of well qualified Islamic enforcement officers, lawyers, and judges. To implement the MHPB, we need enforcement officers, lawyers, judges who are well-versed in the Islamic shariah, especially, in the AITAB principles. Lack of such expertise to the judges and enforcement officers will impede the efficiency of implementation of the Islamic hire purchase law for extension of popular usage by the Muslim community. It is to be inwardly noted that the lackadaisical attitude of the relevant authority in resolving this pressing issue will definitely never merit the torrential blessing from Allah.

${ }^{45}$ Abdullah, 2009, at119. 
Some people in Malaysia propose that the existing Hire Purchase Act 1967 and the Islamic law on hire purchase can be combined together as an attempt to harmonize the two laws with a desired result. But some Muslim scholars strongly support a separate Islamic Hire Purchase Act based on the AITAB principle and do not support the harmonization policy between the HPA 1967 and the shariah law. The concept of harmonization of law means that the shariah principles will be incorporated into the HPA 1967 which is tantamount to harmonizing the Al-Qur'an with the Holy Bible. There can be some similarities in some of the principles but the dissimilarities in the Al-Qur'an will overly and dominantly outweigh the advantages obtained from the little similarities.

\section{Conclusion and Suggestions}

The hire purchase law provides a very good opportunity to customers to rent goods with an option to buy it by paying installment rentals, may be on monthly installments. This law is very beneficial for the people who do not have enough money to pay cash to buy new or second hand goods. The Islamic hire purchase law is of paramount important for the Muslims to conduct their business transactions with a peace of mind as these transactions do not impose interest (riba) on the hirer, in which case, the Muslims can comply with the shariah principles by renting the required goods under the AITAB or al-bai al-murabahah principle.

There are Muslims and non-Muslim citizens in Malaysia while the Muslim religion is substantially different from that of the non-Muslims on certain religious practices, for example, prohibition of interest based (riba) business transactions, avoiding haram (prohibited) goods, avoiding gambling (mysir), avoiding the participation of traditional insurance as it heavily involves interest based transactions throughout its business operation. However, as the non-Muslims' religions do not prohibit them from performing and participating in the interest based business operations, thus, the present Hire Purchase Act 1967 (Malaysia) is applicable for the non-Muslims but not welcomed by the Muslims because of its interest related provisions and the non-prohibition of the transaction of haram (prohibited) goods.

If we propose to incorporate the shariah principles into the HPA 1967 as stated and explained earlier, the probability will be manifestly high indeed that the non-Muslims may protest as they are happy with its present format and contents. However, if we open up our inner mind to explore the intrinsic beauty and the inherent advantages of the AITAB philosophy, we can manifestly discover the concealed superior advantages apart from the main benefits that the law has been so framed and by virtue of this particular concept we are fervently of the opinion that the best solution of the problem would be to enact a separate Islamic Hire Purchase Act for the benefit of the Muslims in Malaysia.

\section{References}

AAOFII Shariah Rules for Investment and Financing Instruments, Article 11(2).

Abdullah, N. I. and Razali, S.S. (2008) Commercial Law of Malaysia, London, Toronto: 
Pearson, Prentice Hall.

Abdullah, N. Irwani. (2005) Islamic Hire Purchase in Malaysian Financing Institutions: A Comparative Analytical Study, Loughborough: Loughborugh University, UK. (Ph.D. thesis)

Abdullah, N. Irwani. (2009) Implementation of Muamalah Hire Purchase Bill in Malaysia: Chasing a Mirage? IIUM Law Journal, 17, 99-123.

Coulson, N.J. (1984) Commercial Law in the Gulf States, London: Graham \& Trotman.

Diamond, A.L. (1971) Introduction to Hire Purchase Law, London: Butterworths.

Dugdale, D. F., (1978) New Zealand Hire Purchase Law, Wellington: Butterworths.

Hasbullah, Abdul Rahman. (2001) The Concept of Contract (aqd) in Islamic Law, The Islamic Quarterly, 45(1).

Humid, Nasser. (2008) Hire Purchase, Malaysia: Gavel Publications.

Islamic Fiqh Academy, Jeddah, Saudi Arabia.

Jalil, Md. Abdul. (2010) Commercial Law in Malaysia (Unpublished monograph).

Majid, Abdul \& Arjunan, Krishnan. (2007) Business Law in Malaysia, Kuala Lumpur: Malayan Law Journal.

Pheng, Lee Mei \& Detta, Ivan Jeron. (2010) Business Law, New York: Oxford University Press.

Ramli, Razli, and Onn, Hasleenda. (2007) Islamic Hire Purchase (Ijarah Thumma Al-bai $A I T A B)$, Kuala Lumpur: Islamic Banking \& Finance Institute Malaysia Sdn Bhd.

Salim, Muhammad Yousuf. (2008) A Handbook on Fiqh for Economists II (Unpublished monograph).

Sathiaseelan, Joshua Kevin. (2008) Hire Purchase, Kuala Lumpur: LexisNexis, Malayan Law Journal.

Usmani, Muhammad Taqi. (2002) An Introduction to Islamic Finance, New York: Kluwer Law International.

Vohrah, Beatrix \& Aun, Wu Min. (2010) The Commercial Law of Malaysia, Malaysia: Longman.

Zuhaily, Wahbah. (2002) Ilmu amalat al-malyyiah al-muaiarah, Damascus: Dar al-Fikr, 393-413.

\section{Legislation}

Age of Majority Act (Malaysia)

Hire Purchase Act 1965 (UK)

Hire Purchase Act 1967 (Malaysia)

Hire Purchase Act 1971 (New Zealand)

Sale of Goods Act 1957 (Malaysia)

Cases:

Credit Corporation (M) Bhd v Malaysian Industrial Finance Corporation \& Anor [1976] 1 MLJ 83;

Helby $v$ Mathews, 1895

Low Ping Ming v MBF Finance Bhd [2000] 2 CLJ 307;

MBF Finance Bhd. v Ting Kah Kuong \& Anor [1993] 3 MLJ 73.

Tractor Malaysia Berhad v Kumpulan Pembinaan Malaysia Sdn. Bhd. [1979] 1 MLJ 129;

Note: Meaning and clarification of certain abbreviations used in this paper. 
THPC $=$ Traditional Hire Purchase Contract.

HPA = Hire Purchase Act 1967 (Malaysia).

IHPL = Islamic Hire Purchase Law.

$\mathrm{AITAB}=$ Al-ijarah thumma al-bai

MHPB = Muamalah Hire Purchase Bill

It is to be noted that THPC has similar meaning and implications with HPA 1967; and IHPL has similar meaning and implications with AITAB and MHPB. 